\title{
Entrevista com SvetLana CÂrstean ${ }^{1}$
}

Hugo Pradelle: Seu livro A flor do torno foi recebido com muito entusiasmo na Romênia. Essa recepção positiva confirmaria uma atenção especial dirigida para a poesia em seu país?

Svetlana Cârstean: O livro teve uma recepção crítica bem inesperada. A escrita desses textos começou há muito tempo - logo depois da Revolução - e me acompanhou até 2003. O livro passou por uma espécie de descanso e só foi publicado em 2008. Essa distância me permite perceber uma mudança de orientação da produção poética na Romênia, que passa por certa efervescência e obedece a dinâmicas de renovação. A cada ano, quatro ou cinco livros revelam novos poetas. A poesia encontrou um lugar na paisagem editorial.

H.P.: Então se lê poesia na Romênia... Na França, ela parece estar quase sempre confinada a uma forma de periferia, quase relegada, pouco lida, desconhecida.

S.C.: Também é uma batalha que precisamos ganhar. Mas acho que estamos no caminho certo. A poesia ocupa um lugar central, ela inventa a língua e sempre a recoloca no centro, ela a perturba e a faz circular. Ao mesmo tempo, ela reforça um sentimento de abertura e um movimento cosmopolita. Os poetas romenos viajam muito, fazem palestras por toda a Europa - da Suécia até a França ou a Alemanha. Eles interrogam a língua, eles a situam e, ao mesmo tempo, a deslocam. Deste modo, penso em autores há pouco consagrados como Simona Popescu ou Angela Marinescu, mas também em Radu Vancu, Dan Sociu, Sorin Ghergut, Dan Coman, Elena Vladareanu, Vasile Leac, Constantin Acosmei, Alice Popescu, Andrei Dosa. E também nos mais jovens como Val Chimic ou Anatol Grosu... A lista seria bem mais longa e, é claro, subjetiva.

\footnotetext{
${ }^{1}$ Svetlana Cârstean nasceu em 1969 em Botosani, no norte da Romênia. É escritora e jornalista e publicou artigos, entrevistas e poemas em revistas como Dilema, Observator Cultural, România literară e Adevărul Literar şi artistic. Seu livro La Fleur d'étau [A flor do torno], publicado em 2008, recebeu alguns dos mais prestigiados prêmios literários da Romênia. E-mail: <svetlanacarstean@yahoo.com>. Entrevista realizada por Hugo Pradelle e publicada em francês em La Quinzaine Litteraire, no 1081, 1 a 15 de abril de 2013.
} 
H.P.: A literatura romena parece assombrada pela ruptura de 1989. As geraçóes posteriores tiveram que lidar com uma nova liberdade e, ao mesmo tempo, com uma agitação intelectual e artística que perturba a tradição.

S.C.: Depois de 1989, veio um período de desinteresse geral pela ficção. Ela foi relegada a segundo plano. Parecia que ela tinha sido tragada pela euforia da liberdade econômica, pela adrenalina política. Nessa época, tivemos que decidir muito rapidamente o que devia ser feito. Estávamos enredados em uma espécie de êxtase difícil de administrar. As pessoas liam memórias, diários de prisão, textos de dissidentes, um pouco como em todos os países que se desvencilhavam da tutela soviética e da censura. Minha geração foi a primeira a se apropriar de novos temas, a inventar outro estilo. Penso em Răzvan Rădulescu, escritor e roteirista romeno publicado na França pela editora Zulma (La Vie et les Agissements d'Ilie Cazane [A vida e as artimanhas de Ilie Cazane]). Desde entáo, a diferença era obrigatória. Para nós, estava claro que era preciso analisar, nos mínimos detalhes, nosso passado imediato. Tínhamos que interromper a relação sombria que mantínhamos com tudo o que nos antecedia. Era preciso fazer alguma coisa com as nossas infâncias, transcorridas durante os anos mais duros do comunismo, recuperar uma memória, travar uma luta com o passado. Assim, reescrevemos as relaçôes com nossos próprios pais e suas escolhas. Era preciso destruir. A geração de hoje se depara com questóes diferentes. Os poetas de hoje precisam fazer alguma coisa diante da mercantilizaçâo do imaginário do comunismo, que nós não tínhamos previsto, inventar outras relaçôes, plurívocas, com o exterior. Estamos em um novo tempo de ruptura que faz com que se reinventem os temas, os estilos. Eles rejeitam um discurso de lamento ou uma nostalgia complexa, eles precisam se distanciar. Desde 1989, parece que passamos de uma homogeneidade, agora inexistente, para uma heterogeneidade de vozes múltiplas. De algum modo, a ideia de grupo se dissolveu para ser substituída por uma busca solitária de uma linguagem singular.

H.P.: Em A quinta impossibilidade, Norman Manea define a lingua como "sentido de pertencimento", a literatura como o "último refúgio da conhecida recusa da resignaçâo" e as palavras como sendo "armas", ferramentas de uma resistência obrigatória. Para você, a poesia constitui uma modalidade da sobrevivência? 
S.C.: Às vezes, a poesia é o único modo de sobrevivência. Acho que quando esse sentido de pertencimento foi fortemente abalado, a possibilidade de saber que pertencemos à nossa própria língua, nossa língua materna, e, sobretudo, à própria linguagem, é algo essencial. O comum se une, assim, ao singular. Meu trabalho poético consiste em um combate para conseguir fazer o luto da minha infância, poder identificar, nomear suas rupturas. É preciso, sobretudo, levá-la em conta, assumi-la. Não se pode seguir sem se desviar, virar, mudar. Manea fala da sobrevivência durante o exílio propriamente dito, ele a inscreve em um deslocamento refundador. Eu falaria mais de um exílio em minha história pessoal, de uma solidão absoluta diante dos meus pais e em meu próprio país. Não se deve esquecer que nossas histórias carregam o destino de nossos ascendentes, esses pais que atravancam as coisas. Nós somos herdeiros, mas, ao mesmo tempo, inventamos algo novo. Foi por meio desse exílio interior que me acostumei, desde cedo, a morar no interior das palavras, com a leitura. Compreendi então, acho que bem rápido, como as palavras podem se tornar um refúgio no qual ficamos a postos, com as armas nas mãos: as armas que herdamos ou as que inventamos.

H.P.: Isso não obriga a uma conciliação entre o intimo e os questionamentos coletivos urgentes?

S.C.: $A$ flor do torno tem quatro partes - $O$ livro do operário ou $A$ flor do torno, O livro dos pais ou Tomo cuidado, prometo, O livro de Akihito ou $O$ amor e $O$ livro da solidão ou Do you yahoo? Ao escrever esses textos, nunca pensei que tratassem do comunismo. O livro não foi concebido como uma metáfora da ditadura. Ele traz em si essas questóes, mas por um viés pessoal, que considera o que eu deveria fazer comigo mesma, o passado do qual eu deveria me livrar. Ele se organiza a partir de uma lembrança que me voltava com frequência. Eu revia os bancos e as bancadas de trabalho na oficina de serralharia em que trabalhava com meus colegas de escola. Eu usava um torno de mesa comum de metal verde escuro e produzia peças idênticas e sempre defeituosas. Reconstruindo essa lembrança, me desloco para o interior do torno e foi ali que escrevi o poema. Desse modo, ocorre uma troca de intimidade, um deslocamento. A flor do torno tinha surgido para colocar uma ordem no informe do íntimo. Mais tarde percebi que meu livro fala também 
de um luto coletivo e que o comunismo que afetou a todos nós durante tanto tempo projetava sua sombra sobre todos os elementos da minha vida, como de todas as vidas. Era preciso se desenredar desse eu complicado diante da complexidade do mundo. Os rastros não podem ser apagados por uma revolução ou pelo roteiro de uma revolução.

H.P.: Escrever poesia é, então, lutar - com a espessura da memória, a densidade dos corpos e do tempo, a presença das vozes?

S.C.: Acho que sim. É sobreviver, manter-se de pé no mundo. Escrever significa reinventar a memória, organizar as vozes, recuperar seu corpo.

Tradução do francês de Marília Garcia (Doutora em Literatura Comparadal UFF, Pós-Doutorado em Literatura Francesal UFRJ) 
Cînd sînt fericită nu scriu.Cînd sînt fericită nu-mi trebuie alte jucării, nu-mi trebuie cărți, prăjituri, bărbați.Astăzi mi s-au crăpat, pentru prima oară, ghetele de lac, ghetele mele cu care am bătutt drumurile atîția ani. Una mai tare, cealaltă mai puțin. Dar pentru mine nu contează care s-a crăpat mai tare. Pentru mine ele sînt la fel. Le iubesc pe amîndouă la fel de mult. Același lucru se întîmplă și cu picioarele mele. Niciodată nu am făcut nici o diferențiere între ele. Ce i-am dăruit unuia, i-am dăruit și celuilalt. Și mi s-au supus în aceeași măsură. N-au existat certuri, disensiuni, remușcări, țipete. Doar cu mîinile am avut probleme. Aceste probleme au început pe la vîrsta de 12 ani. Întîmplător și fără nici o legătură, tot cam pe-atunci au început să-mi crească și sînii. Întîmplător și tot fără nici o legătură, sînul meu stîng a fost întotdeauna mai mic decît cel drept. Eram mai mult singură și ascultam în fiecare dimineață Buletinul hidrologic și cel mai tare îmi plăcea cînd auzeam lenivodezodiudaniubsomeșbestrant și tot așa. Atunci îmi luam mîinile, le așezam în fața mea și începeam să le vorbesc. Întîi calm, apoi din ce în ce mai tare. Pe cea dreaptă o chema Beatrice, nume frumos, pe cea stîngă, Alice, nume urît. Alice era proastă, rea, murdară, neascultătoare. Nu primea nimic de la mine, nici măcar o mîngîiere. Ba dimpotrivă uneori chiar o pocneam și îi spuneam să plece, obligînd-o să stea la spate. Beatrice era strălucitoare și nu mai are rost să-i enumăr calitățile. Beatrice era sufletul meu, o strîngeam la piept și îi spuneam cuvinte dulci, ne mîngîiam reciproc. O puneam să mă hrănească și să-mi scrie temele. Tîrziu de tot cînd $\mathrm{m}$-am căsătorit, Alice a avut parte de o verighetă de aur pe inelarul ei. Și tot din acel moment, Beatrice a rămas destinată argintului și plasticului. Astăzi nu mai știu de Alice și Beatrice și nici pentru atunci nu pot băga mîna în foc dacă Alice o fi fost mîna dreaptă și nu invers. Cînd sînt fericită, nu scriu. Astăzi însă mi s-au crăpat pentru prima oară ghetele mele de lac. Una mai tare, alta mai puțin. Dar pentru mine nu contează. Eu le iubesc la fel de mult pe amîndouă. Nu m-am gîndit niciodată la ele ca fiind două, două lucruri, două ființe pentru care trebuie să am două gînduri diferite. Poate pentru că ele au făcut din mine una singură și poate pentru că, pe măsură ce am crescut și m-am maturizat, sufletul mi-a coborît încet-încet din mîini în picioare. Sufletul 
meu are culoarea vișinie.Alice sau Beatrice? $\mathrm{Nu}$ mai contează. $\mathrm{Nu}$ mai vorbesc de mult cu mîinile mele. Singurătatea mea nu se mai măsoară în lungi conversaţii cu ele, ci în adîncimea inboxului meu gol. Acum Alice stă în fața computerului și îi scrie mesaje lui Beatrice sau poate invers, Beatrice lui Alice. Numele mele de scenă își pierd strălucirea în mijlocul pustiei, unde doar o pereche de ghete solide te pot conduce spre oază. 
Quando estou feliz, não escrevo.

Quando estou feliz, não preciso de outros brinquedos, não preciso de livros, de bolos, de homens.

Hoje, pela primeira vez, as botinas laqueadas, minhas botinas com as quais percorri tantos caminhos anos afora, se romperam.

Uma delas estragou bastante, a outra menos. Para mim, porém, não interessa qual delas está mais rompida. Para mim, elas são a mesma coisa. Amo as duas do mesmo jeito. A mesma coisa acontece com os meus pés. Nunca fiz nenhuma distinção entre um e outro. O que eu dava para um, dava para outro. E serviramme na mesma medida. Não houve brigas, divergências, remorsos ou gritos. Só com as mãos é que tive problemas. Esses problemas começaram quando eu tinha 12 anos. Por acaso e sem nenhuma conexão, também mais ou menos naquela altura meus seios começaram a crescer. Por acaso e também sem nenhuma conexão, meu seio esquerdo sempre foi menor do que o direito. Eu era muito mais sozinha e escutava todos os dias de manhã o Boletim hidrológico e o mais legal era quando eu ouvia lenivodezodiudaniubsomeşbestrant e tudo o mais. Entáo eu levava as mãos diante do rosto e começava a falar com elas. Primeiro calmamente, depois cada vez mais alto. A da direita se chamava Beatrice, nome bonito, e a da esquerda Alice, nome feio. Alice era estúpida, ruim, suja e desobediente. De mim, não ganhava nada, nem mesmo um carinho. Às vezes eu até mesmo batia nela e dizia-lhe que fosse embora, obrigando-a a ficar nas costas. Beatrice era brilhante e não faz mais sentido elencar suas qualidades. Beatrice era a minha alma. Eu a apertava contra o peito e dizia-lhe palavras doces. Nos acariciávamos uma à outra. Eu a punha para me alimentar e fazer meus deveres. Bem mais tarde, quando me casei, Alice ganhou uma aliança de ouro para o seu anelar. E, também naquele momento, Beatrice ficou destinada à prata e ao plástico. Hoje, de Alice e Beatrice não sei mais nada, e nem por aqueles tempos posso pôr minha mão no fogo para dizer se Alice teria sido a mão direita e não o contrário.

Quando estou feliz, não escrevo. Hoje porém, pela primeira vez, romperam-se as minhas botinas laqueadas. Uma delas estragou bastante, a outra menos. Para mim, porém, não interessa. Amo as duas do mesmo jeito. Nunca pensei nelas como sendo duas, duas 
coisas, dois seres para os quais preciso de dois pensamentos diferentes. Talvez porque elas tenham feito de mim uma só e talvez porque, à medida que cresci e amadureci, minha alma desceu devagarzinho das mãos para os pés. Minha alma tem cor de cereja.

Alice ou Beatrice? Já não importa. Faz muito tempo que não falo com as minhas mãos. A minha solidão não se mede mais em longas conversas com elas, mas na profundidade do vazio da minha caixa de mensagens. Alice está agora na frente do computador e escreve mensagens para Beatrice, ou talvez o contrário, Beatrice para Alice. Meus nomes de cena perdem seu brilho no meio do deserto, onde apenas um par de botinas sólidas pode te conduzir para oásis.

Tradução do romeno de Raul Passos (Graduado pela EMBAP/ Escola de Música e Belas Artes do Paraná e Mestrando pela UNMB/Universidade Nacional de Música de Bucareste) 